\title{
Palynological investigations of Permian rocks from Nordaustlandet, Svalbard
}

\author{
GUNN MANGERUD and ROGER M. KONIECZNY
}

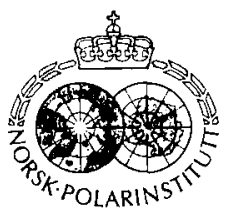

\begin{abstract}
Mangerud, G. \& Konieczny, R. M. 1991: Palynological investigations of Permian rocks from Nordaustlandet, Svaibard. Polar Research 9(2). 155-167.

Palynological investigations of nine sections covering the upper part of the Nordenskiöldbreen Formation, Gipshuken Formation, and the lower part of the Kapp Starostin Formation in the Wahlenbergfjorden area. Nordaustlandet, yielded palynomorphs in three sections. Three assemblages are recognized. A tentative correlation with the Sverdrup Basin suggests a Sakmarian to Artinskian age for the uppermost Nordenskiöldbreen and lower Gipshuken Formations. Thermal maturity is low. The palynoflora is dominated by striate pollen suggesting an arid climate throughout the deposition of the Nordenskioldbreen and Gipshuken Formations.
\end{abstract}

Gunn Mangerud, Continental Shelf and Petroleum Technology Research Institute (IKU), N-7034 Trondheim, Norway; Roger M. Konieczny, Norwegian Institute for Water Research (NIVA), P.O. Box 69 Korsvoll. N. 0808 Oslo 8. Norway.

Permian and Carboniferous strata crop out at several localities in the Svalbard Archipelago. The chronostratigraphic relations of the rock units are uncertain because the biostratigraphical con- trol for the Permian is poor. Fusulinids are present in the Nordenskiöldbreen Formation (Forbes 1960; Cutbill \& Challinor 1965; Ross 1965; Nilsson 1988) giving a Sakmarian age in upper parts.

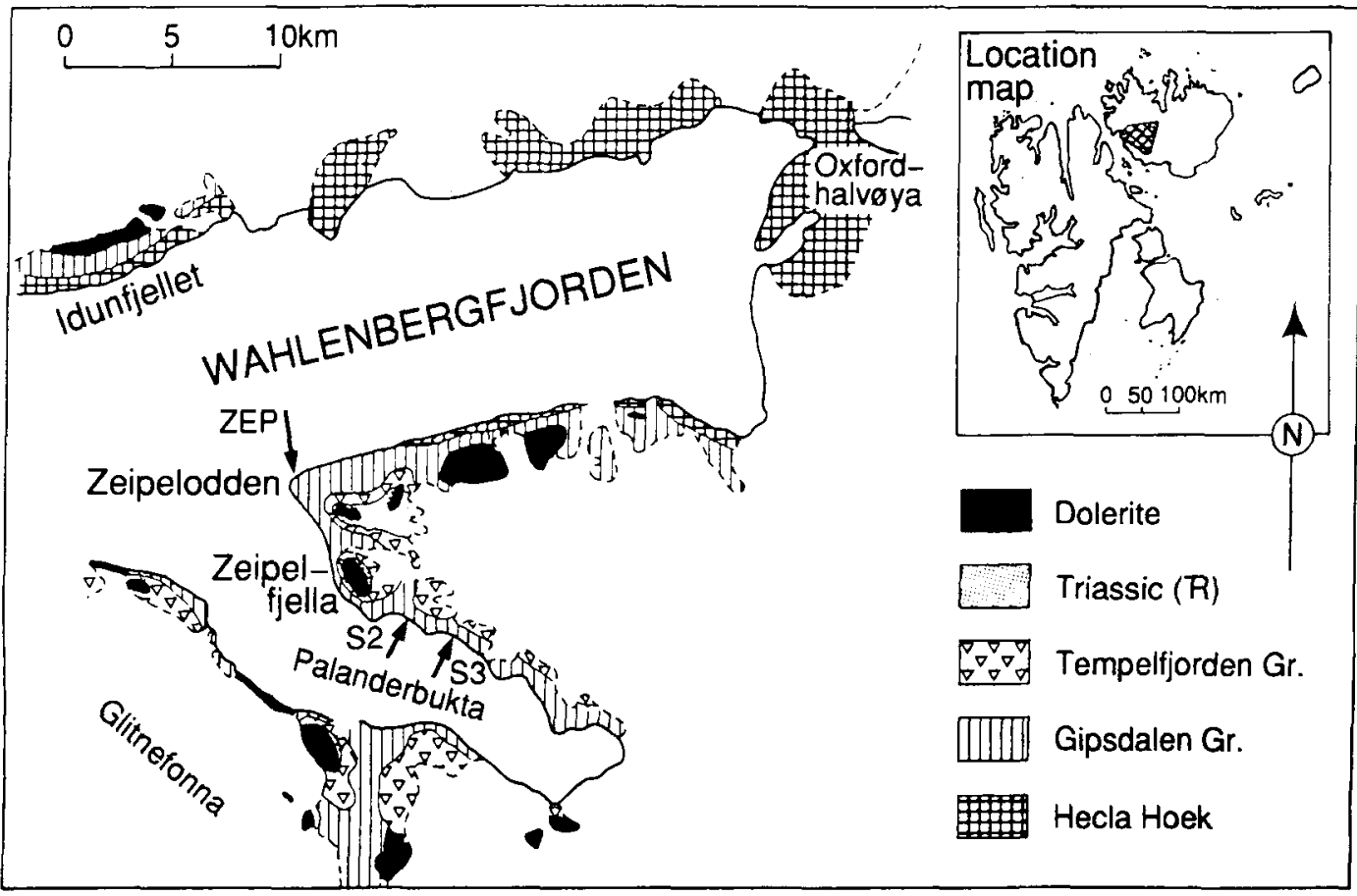

Fig. 1. Geological map of the study area around Wahlenbergfjorden. Nordaustlandet Island, in the Svalbard Archipelago (after Lauritzen 1981). Arrows ZEP. S2 and S3 indicate Zeipelodden (ZEP) and Palanderbukta (S2 and S3) sections, respectively. 


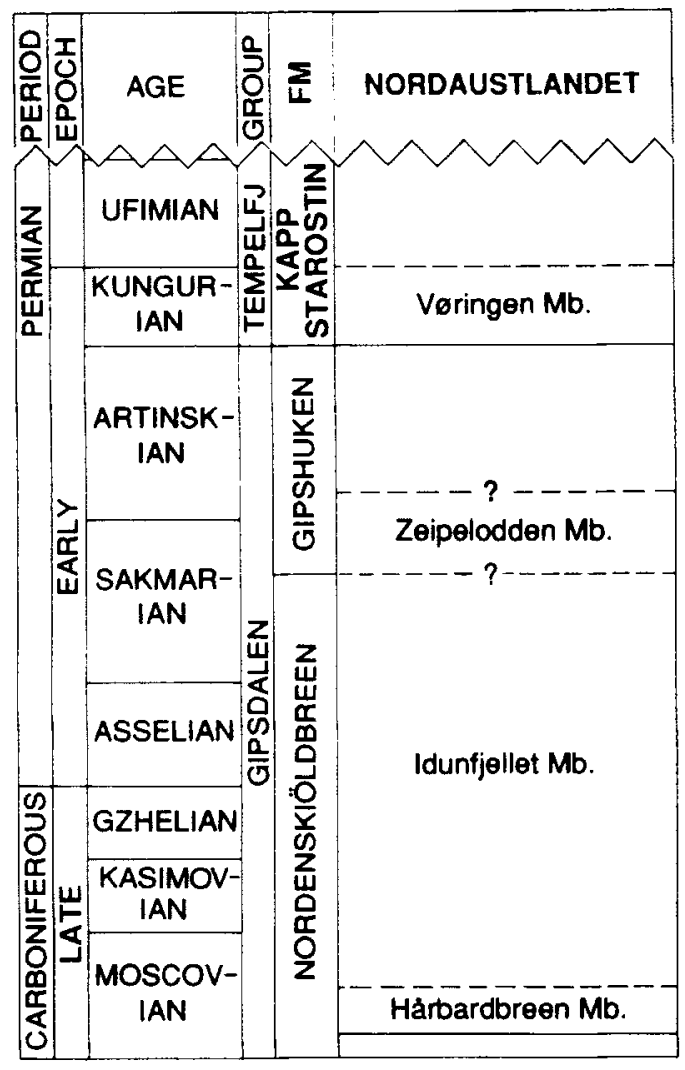

Fig. 2. Stratigraphical scheme for Nordaustlander (Based on data from Cutbill \& Challinor 1965. Laurizen 1981. and the present study)

Ammonoids are rarely present (Frebold 1939). For the Kapp Starostin Formation no biostratigraphic subdivision is made. but brachiopods recorded suggest a Kungurian to Dzhulfian age (Nakamura et al. 1987), while the conodont fauna is correlated with Roadian deposits (Malkowski 1982). Palynological works published from the Paleozoic succession on Spitsbergen and Bjørnøya are from the Devonian and Carboniferous and include Playford (1962, 1963). Vigran (1964). Allan (1965), Dibner (1968) and Kaiser (1970, 1971). The aim of this ongoing study is to establish a palynological zonation for the Permian succession of Svalbard and the Barents Sea region.

Carboniferous and Permian deposits in Nordaustlandet. Svalbard, were investigated by the Norwegian Polar Research Institute during an expedition in 1974. and M. B. Edwards measured 9 sections and initiated palynological investi- gations. The preliminary results from this reconnaissance study were presented by J. O. Vigran at the annual meeting of the Norwegian Geological Society in 1976.

This paper presents age determinations, thermal alteration indices and comments on environmental interpretations based on palynology for the three productive sections, one at Zeipelodden and two at Palanderbukta (Fig. 1). The investigated succession ranges from the upper part of the Nordenskiöldbreen Formation (Idunfjellet Member), through Gipshuken and the lower Kapp Starostin (Vøringen Member) Formations (Fig. 2). The lithostratigraphy for the sections (Figs. 3 and 4) is based on unpublished field logs from M. B. Edwards and partly from data given by Lowell (1968) and Lauritzen (1981).

Lauritzen (1981) established a preliminary lithostratigraphic division in this area and presented new data on the age of the lower part of the succession on Nordaustlandet. Based on fusulinids, a late Moscovian age was indicated for the lowermost part of the Idunfjellet Member (Nordenskiöldbreen Formation).

\section{Description of the area}

\section{Location}

The Wahlenbergfjorden (Fig. 1) is situated on the western side of the island Nordaustlandet, which is located northeast of Spitsbergen in the Svalbard Archipelago. Most of the island is covered by glaciers, and bedrock exposures are restricted to the narrow area between the sea and the inland glaciers. The two productive sections from Pal-

LITHOLOGY, SEDIMENTARY STRUCTURES \& FOSSILS

\begin{tabular}{|c|c|}
\hline & Mudstone/ shale \\
\hline & Sandstone \\
\hline T्य & Limestone \\
\hline $8 \frac{9}{60}$ & Sandy limestone \\
\hline [x] & Cherty limestone \\
\hline सB & Dolomite \\
\hline$C$ & Covered \\
\hline 0.0 & Breccia \\
\hline 5 & Siderite concretion \\
\hline & Calcite concretion \\
\hline
\end{tabular}

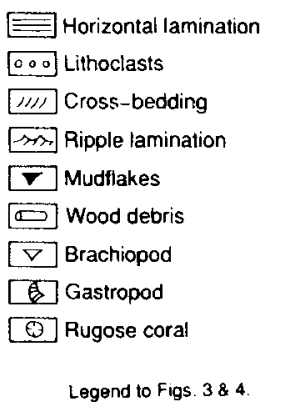




\section{PALANDERBUKTA}

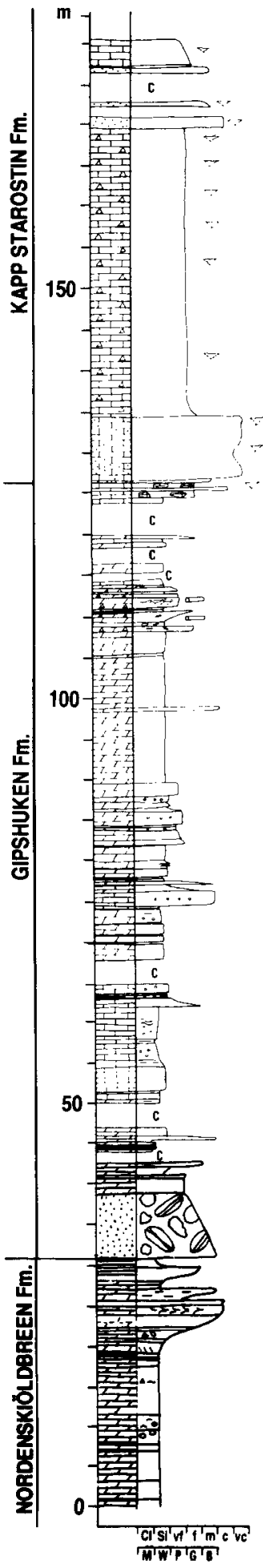

\section{ZEIPELODDEN}

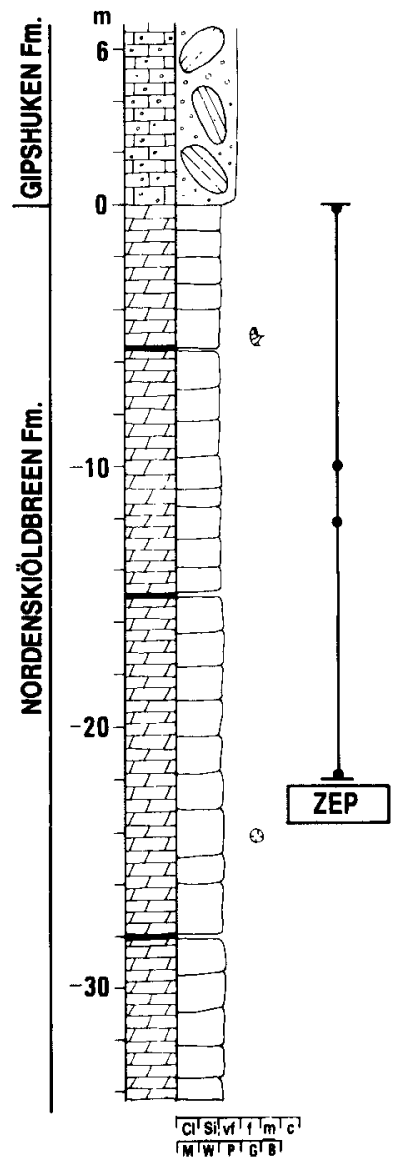

Fig. 4. Lithological section with sample levels in metres below basc Gipshuken Formation for the Zeipelodden loculity (ZEP). (Reconstructed in parts from data given by Lowell 1968. Lauritzen 1981, and by unpublished sample descriptions).

Fig. 3. Lithological composite section with sample levels for the Palanderbukta localities (S2, S3). Scale in metres above base of exposure. (Based on unpublished field logs by M. B. Edwards). 


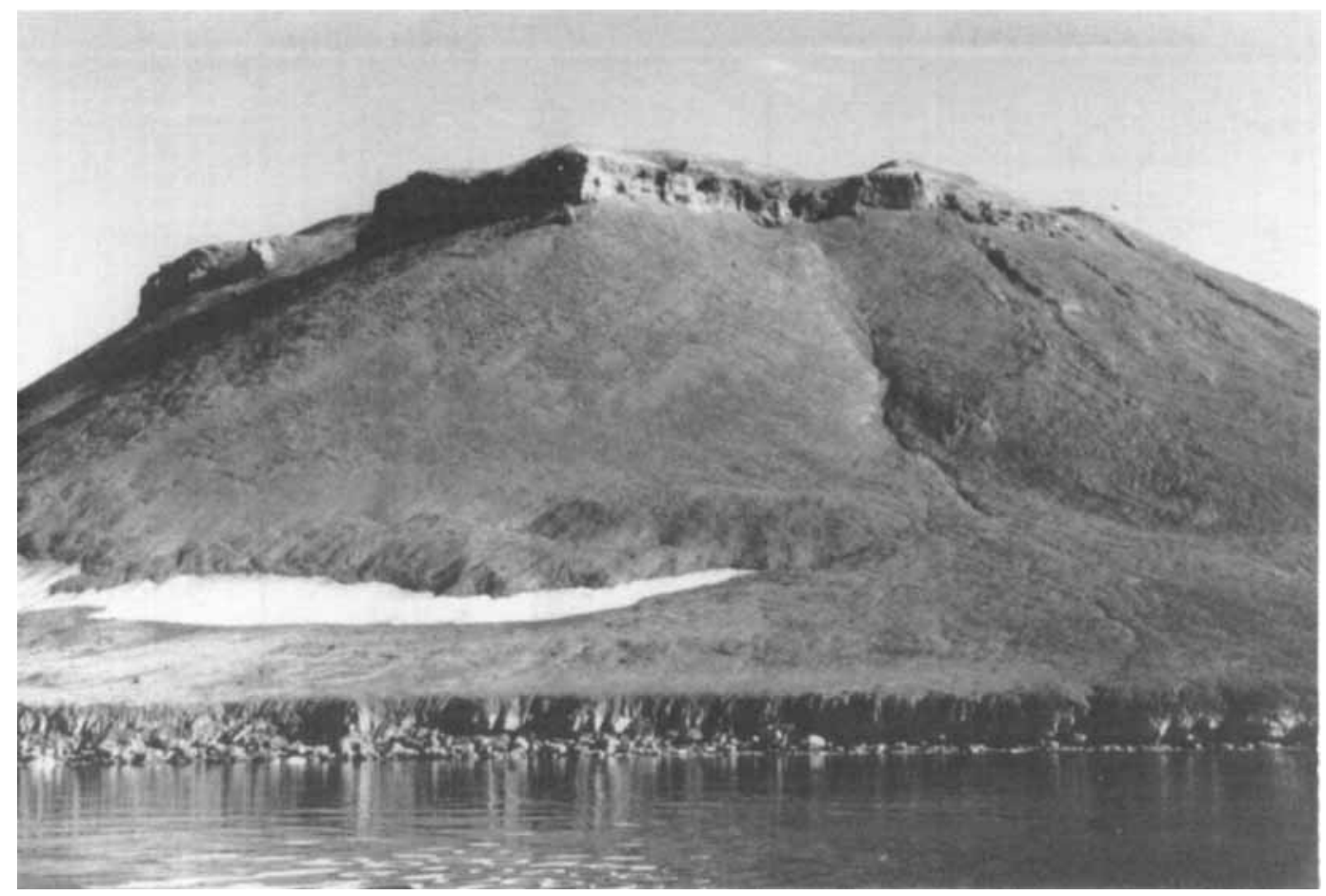

Fig. 5. Zeipelodden locality with the Nordenskiöldbreen and Gipshuken Formations. The Nordenskioldbreen Formation is mostly scree covered, but exposed sections occur at the beach and below the steep cliff on top of the mountain representing the Gipshuken Formation, Photo: H. B. Keilen, Norwegian Polar Rescarch Institute

anderbukta are located along the northeastern shore of the Palanderbukta embayment, an arm of Wahlenbergfjorden. The samples studied (Fig. 3) represent a composite section ( $\mathrm{S} 2$ and $\mathrm{S} 3$ ). comprising about 30 metres of the upper Idunfjellet Member. 75 metres of the Gipshuken Formation. and 55 metres of the Vøringen Member. The section from the Zeipelodden locality (Figs. 4 and 5 ) is located at the junction between the outer Palanderbukta and the southern shore of Wahlenbergfjorden. Four samples are derived from the upper 22 metres of the exposed section assigned to the Idunfjellet Member (Fig. 4). Most of the outcrop is covered by scree.

\section{Stratigraphy and lithology}

The upper Paleozoic sediments in the southwestern part of Nordaustlandet were deposited with an angular unconformity upon the Hecla Hoek basement (Lauritzen 1981). The sequence was folded and eroded prior to the Moscovian transgression which initiated the deposition of the upper Paleozoic succession. There is no record of Devonian sediments in this area. The Nordenskiöldbreen and Gipshuken Formations are characterized by carbonate and quartzitic interbeds, while silicified rocks dominate the Kapp Starostin Formation (Lauritzen 1981).

According to Lauritzen (1981) the lowermost part of the succession on Nordaustlandet is clearly transgressive with fossiliferous beds above the basal Hărbardbreen Member dated by fusulinids as late Moscovian. The total upper Paleozoic succession below the Tempelfjorden Group in the Wahlenbergfjorden area was assigned to the Gipshuken Formation by Cutbill \& Challinor (1965). The lower parts were redefined and assigned to the Nordenskiöldbreen Formation by Lauritzen (1981), who stated that a 150-metre thick sequence occurs below typical Gipshuken sediments and forms the base of the upper Paleozoic sequence. The formation has its type section at Idunfjellet. The upper part of the Idunfjellet Member (Fig. 2) is laterally equivalent to the Tyrellfjellet Member on Central Spitsbergen. 
Table 1. Samples studied from the Palanderbukta locality.

\begin{tabular}{lrlll}
\hline $\begin{array}{l}\text { Section } \\
\text { reference }\end{array}$ & Level & $\begin{array}{l}\text { Stratigraphic unit } \\
\text { formation/member }\end{array}$ & Lithology & TAI \\
\hline S3 & $101 \mathrm{~m}$ & K. Starostin/Vøring & shale & $1+-2-$ \\
S3 & $73 \mathrm{~m}$ & Gipshuken & shale & $1+\cdot 2-$ \\
S3 & $46 \mathrm{~m}$ & Gipshuken & shale & $1+-2-$ \\
S3 & $36 \mathrm{~m}$ & Gipshuken & shale & $1+-2$ \\
S3 & $11 \mathrm{~m}$ & Gipshuken & shale & $1+\cdot 2-$ \\
S3 & $8 \mathrm{~m}$ & Nordensk./Idunfj & shale & $1-2-$ \\
S2 & $31 \mathrm{~m}$ & Nordensk./Idunfj & limest. & $1+1+$ \\
S2 & $24 \mathrm{~m}$ & Nordensk./Idunfj & limest. & $2-$ \\
S2 & $22 \mathrm{~m}$ & Nordensk./Idunfj & shale & $1+-2$ \\
S2 & $19 \mathrm{~m}$ & Nordensk./Idunfj & limest. & $1+-2$ \\
S2 & $17 \mathrm{~m}$ & Nordensk./Idunfj & sandst. & $1-2-$ \\
S2 & $9 \mathrm{~m}$ & Nordensk./Idunfj & shale & $2-$ \\
S2 & $8 \mathrm{~m}$ & Nordensk./Idunfj & shale & $2--2$ \\
S2 & $7 \mathrm{~m}$ & Nordensk./Idunfj & shalest. & nearly barren \\
S2 & $3 \mathrm{~m}$ & Nordensk./Idunfj & nearly barren \\
S2 & $1 \mathrm{~m}$ & &
\end{tabular}

The Gipshuken Formation was described by Cutbill \& Challinor (1965), while its equivalent was described from Zeipelodden at Nordaustlandet by Lauritzen (1981). Near the base of the Gipshuken Formation, a limestone breccia defined as the Zeipelodden Member often occurs. Above this member, resting with an erosive contact on top of the breccia, well-bedded sediments of fine-grained limestones interbedded with conglomeratic horizons are found (Lauritzen 1981).

The Kapp Starostin Formation was first described by Hoel \& Orvin (1937) and was later formally described by Cutbill \& Challinor (1965), who subdivided the formation into three members. The lower Vøringen Member occurs in the studied section on Nordaustlandet (Fig. 2) and is dominated by richly fossiliferous biosparites, with conglomeratic and shaly layers (Lauritzen 1981).

\section{Materials and methods}

The palynological samples include limestone, shale and sandstone and were given standard palynological treatment (oxidation) to clean the organic residues before mounting in glycerine jelly. Out of 71 samples processed, 34 contained some organic material, and only 20 of these contained palynomorphs. When possible, 200 specimens were counted. An alphabetical list of recorded species is provided below, and samples studied from the Palanderbukta and Zeipelodden localities are listed in Tables 1 and 2, corresponding to sample levels plotted along the lithological log.

The Thermal Alteration Index (TAI) was assessed from the colour of spores and pollen in unoxidized organic residue after standard palynological preparation. A five division scale was used (Utting et al. 1989).

\section{Assemblage characteristics}

Three assemblages could be distinguished from the measured sections at Palanderbukta and Zeipelodden. The vertical distribution of species is given in Fig. 6. Table 3 provides an alphabetical list of the recorded palynomorphs with references to illustrated specimens (Figs. 7-10).

The oldest assemblage recorded from the Idunfjellet Member and the lowest part of the Gipshuken Formation is dominated by pollen of Protohaploxypinus and Vittatina, and contains

Table 2. Samples studied from the Zeipelodden locality.

\begin{tabular}{|c|c|c|c|}
\hline $\begin{array}{l}\text { Section } \\
\text { reference }\end{array}$ & Level & $\begin{array}{l}\text { Stratigraphic unit } \\
\text { formation/member }\end{array}$ & Lithology \\
\hline ZEP & $0.5 \mathrm{~m}$ & Nordensk./Idunfj & shale \\
\hline ZEP & $10 \mathrm{~m}$ & Nordensk./Idunfj & shale \\
\hline ZEP & $13 \mathrm{~m}$ & Nordensk./Idunfj & shale \\
\hline ZEP & $22 \mathrm{~m}$ & Nordensk./Idunfj & shale \\
\hline
\end{tabular}




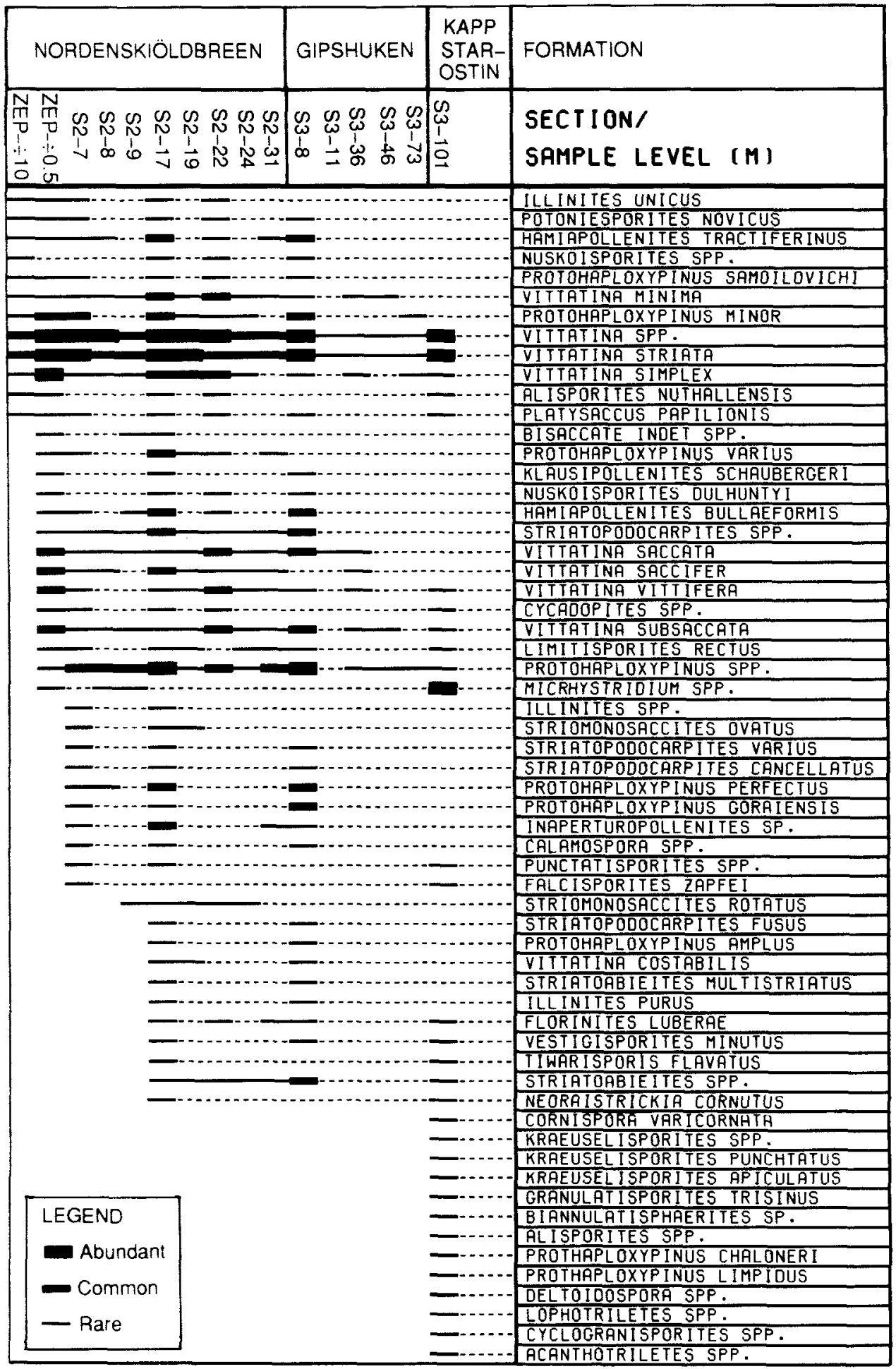

Fig. o. Vertical distribution chart of palynomorphs based on selected samples from the Zeipelodden and Palanderbukta sections. The two samples ZEP- $\div 0.5$ and ZEP- $\div 10$ might be lateral equivalents to some of the samples from section S2. 
Table 3. Recorded palynomorphs listed alphabetically with reference to illustrated specimens (Figs. 7-10).

\section{Spores:}

Acanthotriletes spp.

Biannulatisphaerites sp. (Fig. 7B)

Calamospora spp.

Cornispora varicornata Staplin \& Jansonius 1961 Remark: This species is a reworked Carboniferous spore.

Cyclogranisporites spp. Remark: Dense granulated exine. Deltoidospora spp.

Granulatisporites trisinus Balme \& Hennelly 1956 (Fig. 7D).

Kraeuselisporites apiculatus Jansonius 1962.

Kraeuselisporites punctatus Jansonius 1962.

Kraeuselisporites spp. (Fig. 7C).

Lophotriletes spp. Remark: Exine with scattered coni and rare baculac.

Neoraistrickia cornutus (Andreyeva) Hart 1965 (Fig. 7A).

Punctatisporites spp

Bisaccatc pollen:

Alisporites nuthallensis Clarke 1965.

Alisporites spp. (Fig. 7E).

Bisaccate indet. sp. (Fig. 8C)

Falcisporites zapfei (Potonic \& Klaus) Leschik 1956.

Hamiapollenites bullaeformis (Samoilovich) Jansonius 1962 (Fig. 8E).

Hamiapollenites tractiferinus (Samoilovich) Jansonius 1962 (Fig. $8 \mathrm{~F}$ ).

Illinites purus Leschik 1956.

Illinites spp.

Illinites unicus Kosanke 1950.

KIausipollenites schaubergeri (Potonie \& Klaus) Jansonius 1962. Limitisporites rectus Leschik 1956.

Platysaccus papilionis Potonie \& Klaus 1954.

Protohaploxypinus amplus (Balme \& Hennelly) Hart 1964 (Fig. 7F).

Protohaploxypinus chaloneri Clarke 1965.

Protohaploxypinus goraiensis (Potnoie \& Klaus) Leschik 1956 (Fig. 9A).

Protohaploxypinus limpidus (Balme \& Hennelly) Balme \& Playford 1968.

Protohaploxypinus minor (Klaus) Clarke 1965.

Protohaploxypinus perfectus (Naumova ex. Kara-Murza) Samoilovich 1953.

Protohaploxypinus samoilovichi (Jansonius) Hart 1964 (Fig. 8B). Protohaploxypinus spp.

Protohaploxypinus varius (Bharadwaj) Balme 1970 (Fig. 8A). Striatoabieites multistriatus (Balme \& Hennelly) Hart 1964 (Fig. 8D).

Striatoabieites spp.

Striatopodocarpites cancellatus (Balme \& Hennelly) Hart 1965. Striatopodocarpites fusus (Balme \& Hennelly) Potonic 1958.

Striatopodocarpites phalleratus (Fig. 8H).

Striatopodocarpites spp.

Striatopodocarpites varius (Leschik) Hart 1964 (Fig. 8G).

Monosaccate pollen:

Florinites luberae Samoilovich 1953.

Nuskoisporites dulhuntyi Potonie \& Klaus 1954 (Figs. 9D/E). Nuskoisporites spp.

Potoniesporites novicus Bharadwaj 1954.

Striomonosaccites ovatus Bharadwaj 1962 (Fig, 9C).

Striomonosaccites rotatus (Bharadwaj) Hart 1965 (Fig. 9B).

Vestigisporites minutus (Balme \& Hennelly) Potonie 1958.
Polyplicate pollen:

Tiwarisporis flavatus Maheswari \& Kar 1967 (Fig. 10F).

Remark: The more or less evenly distributed verrucae distinguish this species from Vittatina.

Vittatina costabilis Wilson 1962.

Vittatina minima Jansonius 1962.

Vittatina saccatu (Hart) Jansonius 1962 (Fig. 10C).

Vittatina saccifer Jansonius 1962.

Vittatina simplex Jansonius 1962 (Fig. 10D).

Vittatina spp.

Vittatina striata (Luber) Jansonius 1962 (Fig. 10B).

Vittatina subsaccata Samoilovich 1953 (Fig. 10A)

Vittatina vittifera (Luber \& Walts) Samoilovich 1953 (Fig. 10E).

Monosulcate pollen:

Cycadopites spp.

Alete pollen:

Inaperturopollenites spp.

Acritarchs:

Micrhystridium spp. (Fig. 10G).

Hamiapollenites tractiferinus (Fig. 6). Species of Vittatina comprise about $70 \%$ of the assemblage. and striate, bisaccate pollen account for a maximum of $30 \%$. Characteristic monosaccate pollen (Nuskoisporites, Potoniesporites and Striomonosaccites) quantitatively represent a very small proportion of the total assemblage, with a maximum of $2 \%$. Spores are very rare and acritarchs were recorded in variable but small numbers.

The palynomorphs recovered from the middle and upper parts of the Gipshuken Formation were poorly preserved. The assemblage contained few specimens and were less diverse than the underlying assemblage (Fig. 6). Species of the Vittatinagroup continued to dominate, and monosaccate pollen was absent. The youngest assemblage, represented in one sample from the Vøringen Member of the Kapp Starostin Formation, differs from the two other assemblages by the content of Micrhystridium representing about $85 \%$ of the total assemblage. Several spore genera also appear at this level. Some of these may be reworked from older, probably Carboniferous deposits (Fig. 6).

\section{Age discussion}

A tentative correlation to the Sverdrup Basin is made on assemblage characteristics, although few age diagnostic palynomorphs were recorded. The palynological assemblages from the Sverdrup 

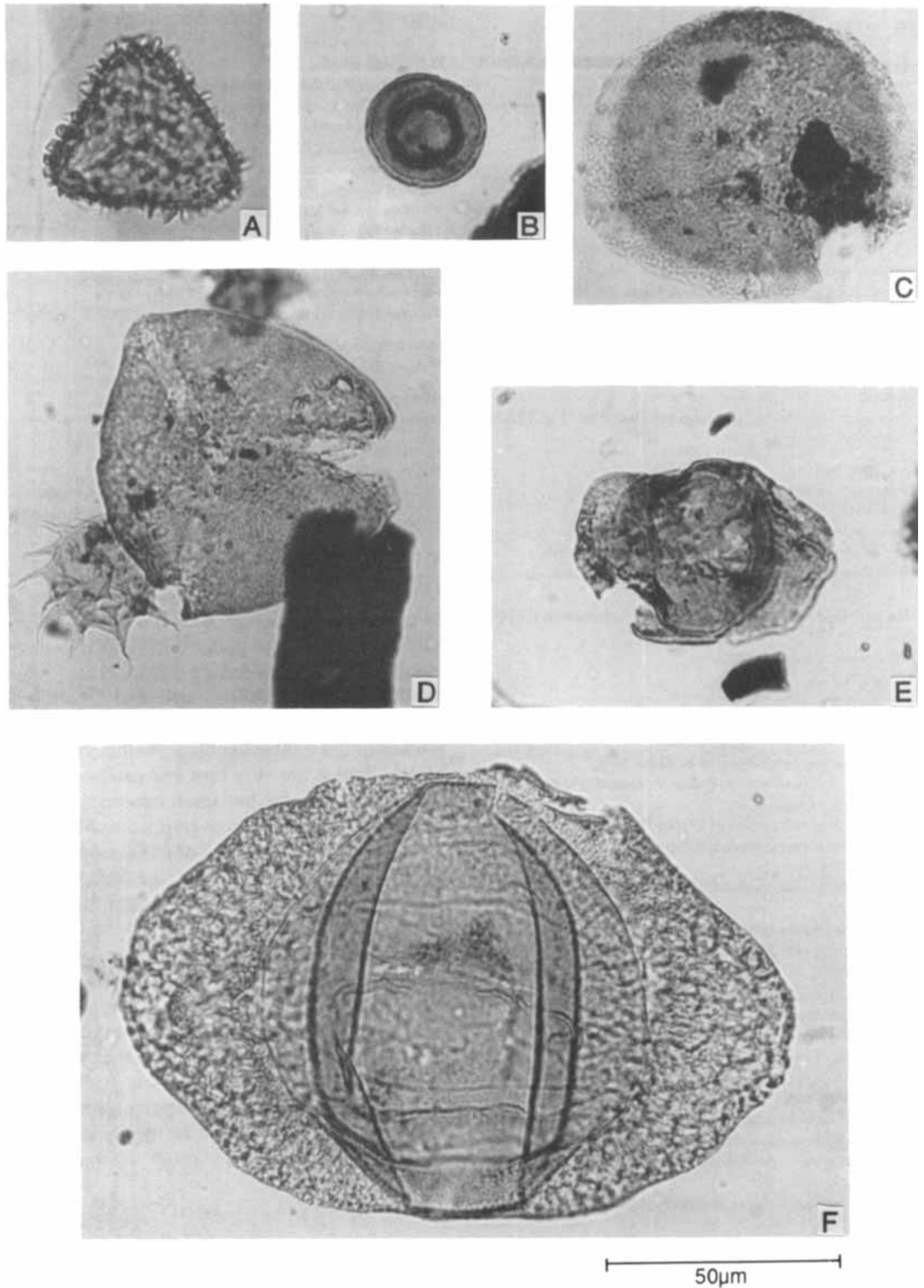

Fig. 7. Selected spores and pollen from Nordaustlandet. Each figured palynomorph is located by abbreviated section name, sample level, and PMO number (Palaeontological Museum in Oslo) followed by slide coordinates to an England Finder. Magnification $\times 700$. Scale is added.

A. Neoraistrickia cornutus S2 $17 \mathrm{~m}$. PMO 121.764. J21.

B. Biannulatisphaerites sp. S3,101 m, PMO 121.767, V11.

C. Kraeuselisporites sp. S3, $101 \mathrm{~m}$, PMO 121. 121.766. E23.
D. Granulatisporiles trisinus S3, $101 \mathrm{~m}$, PMO 121.768, M11.

E. Alisparites sp. S2, 7 m. PMO 121.769. W27.

F. Protohaploxypinus amplus S2. $17 \mathrm{~m}$. PMO 121.765, M29. 

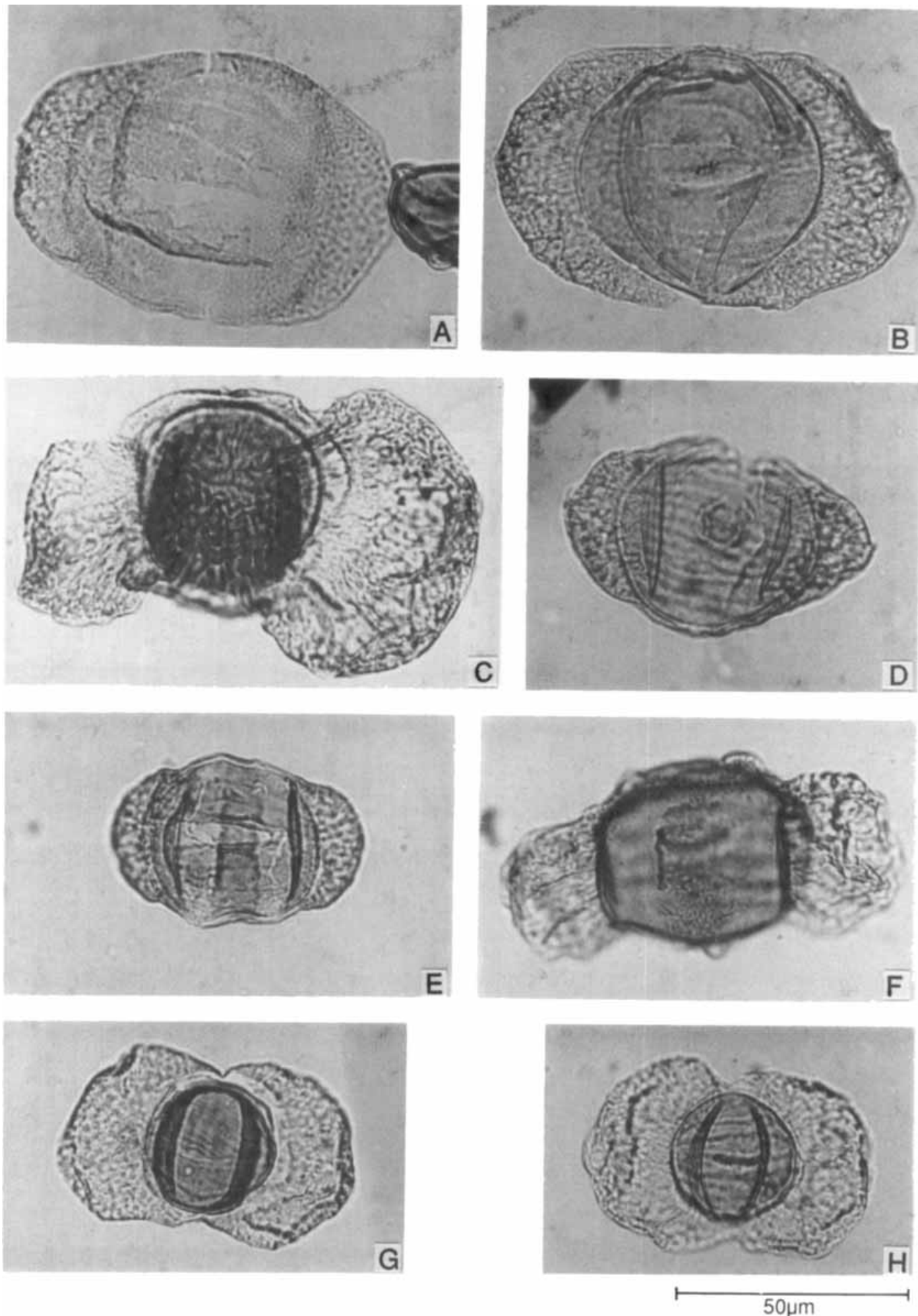

Fig. 8. Selected pollen from Nordaustlandet. Each figured palynomorph is located by abbreviated section name, sample level and PMO number (Palaeontological Museum in Oslo) followed by slide coordinates to an England Finder, Magnification $\times 700$. Scale is added.
A. Protohaploxypinus varius S2, $17 \mathrm{~m}, \mathrm{PMO} 121.763, \mathrm{~F} 18$.
E. Hamiapollenites bullaeformis S2, $17 \mathrm{~m}, \mathrm{PMO} 121.763 . \mathrm{V} 29$
B. Protohaploxypinus samoilovichi, S2, $17 \mathrm{~m}$, PMO 121.763. O31.
C. Bisaccate indet, sp. S2, $17 \mathrm{~m}$, PMO 121.765, $\mathrm{J} 13$
F. Hamiapollenites tractiferinus $\mathrm{S} 2,17 \mathrm{~m}$. PMO 121.765. S20
D. Striatoabieites multistriatus S2, $17 \mathrm{~m}$. PMO $121.765, \mathrm{~V} 15$
G. Striatopodocarpites varius S2, $17 \mathrm{~m}$, PMO 121.763, N19.
H. Striatopodocarpites phalleratus S2.17 m. PMO 121.765. O29. 


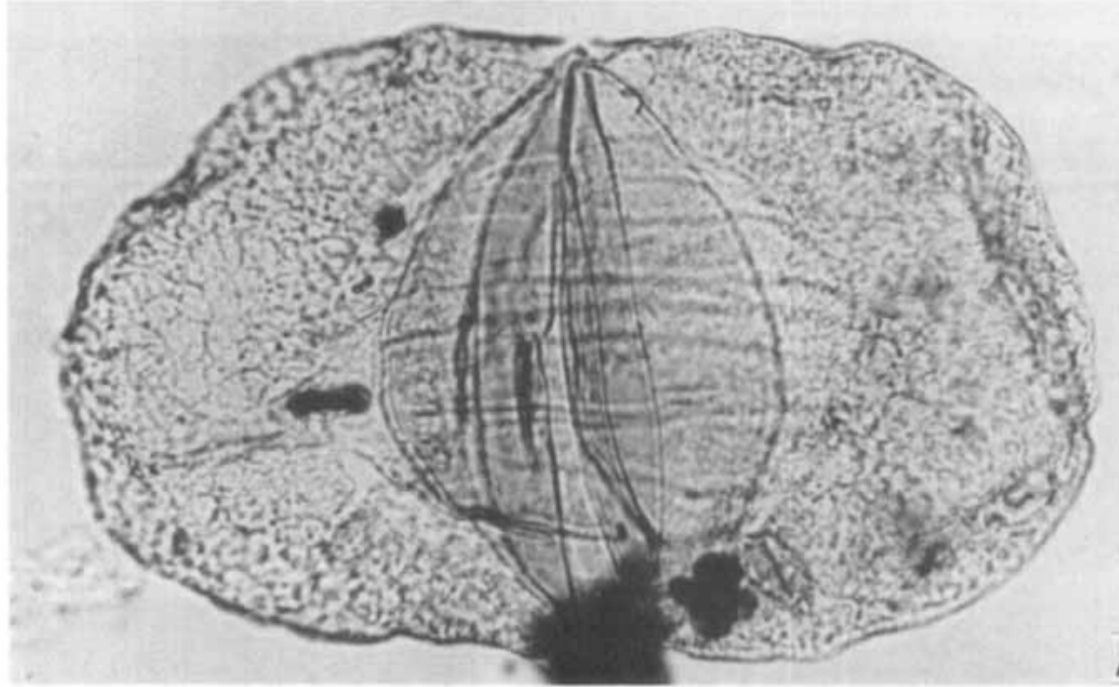

A
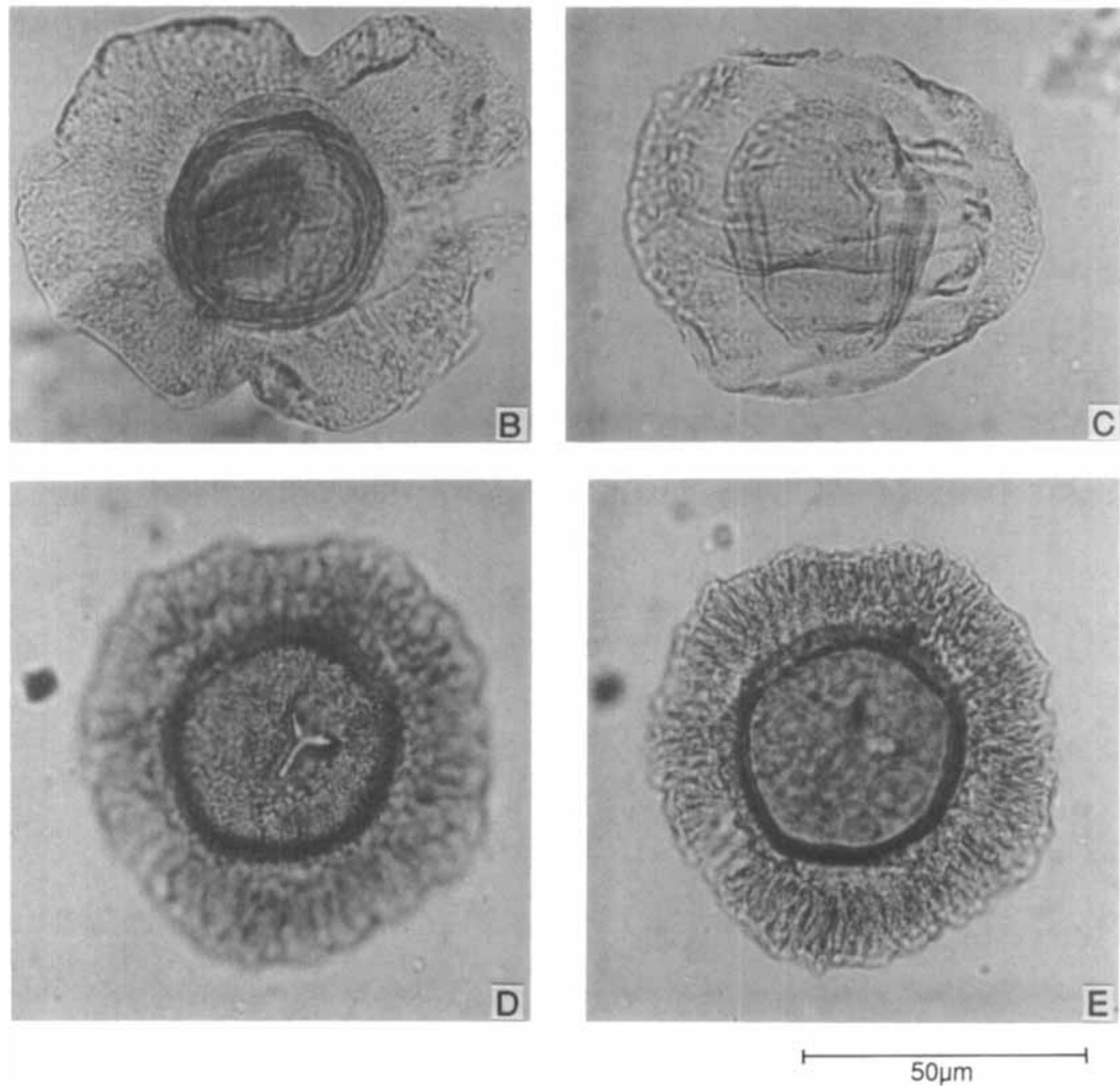

Fig. 9. Selected pollen from Nordaustlandet. Each figured palynomorph is located by abbreviated section name, sample level and PMO number (Palacontological Museum in Oslo) followed by slide coordinates to an England Finder. Magnification $\times 700$. Scale is added.

A. Protohaploxypinus goraiensis S2. $17 \mathrm{~m}$. PMO 121.764. W13.

B. Striomonosaccites rotatus $\$ 2.17 \mathrm{~m}$. PMO 121.763. X18.

C. Striomonosaccites orutus S2. $17 \mathrm{~m}$. PMO 121.763. O19.

D. E. Nuskoisporites dulhuntvi (Same specimen in proxımal and distal focus) $\$ 2.17 \mathrm{~m}$. PMO 121.765. M23. 

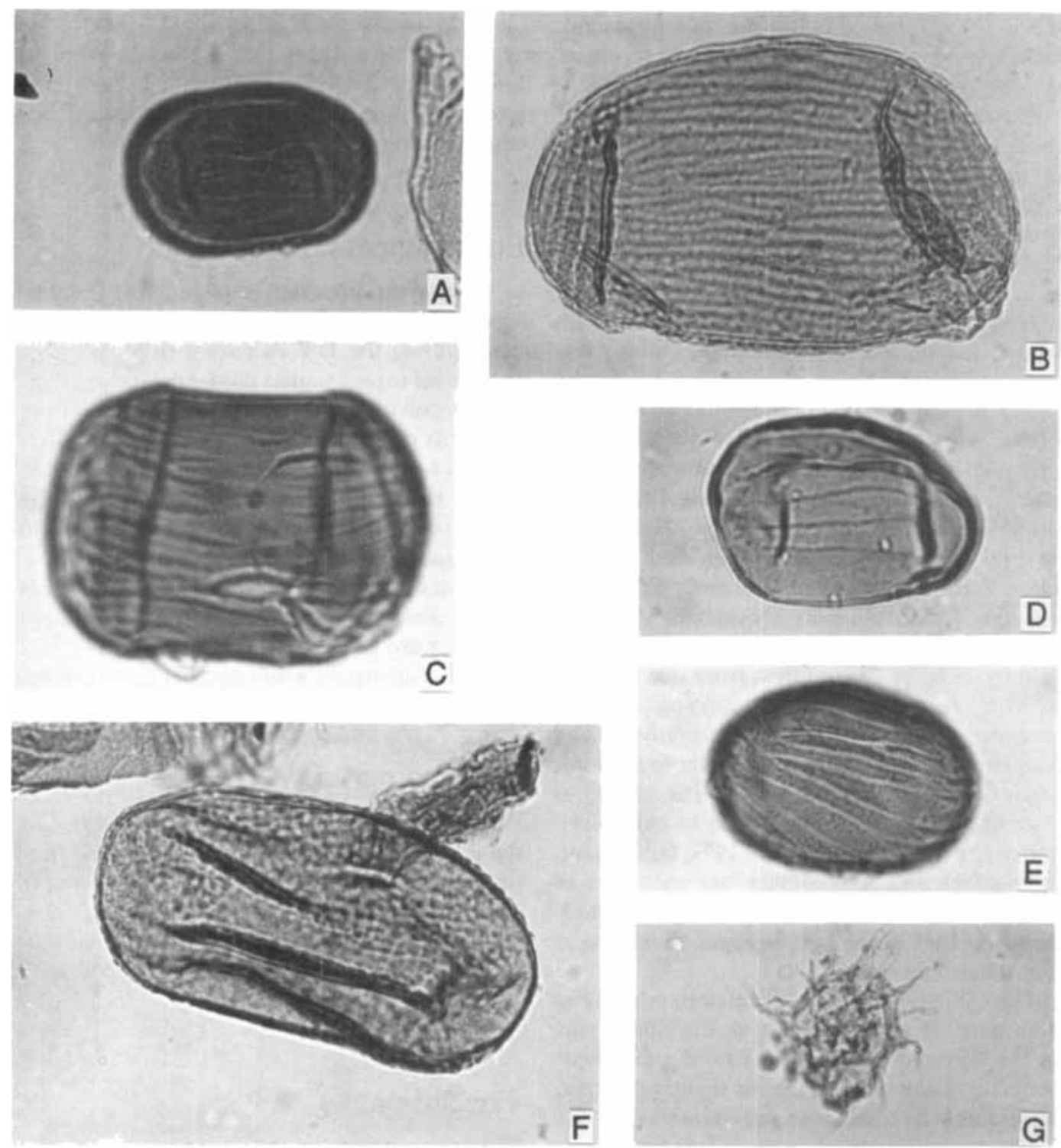

$\overline{\mathrm{C}}$
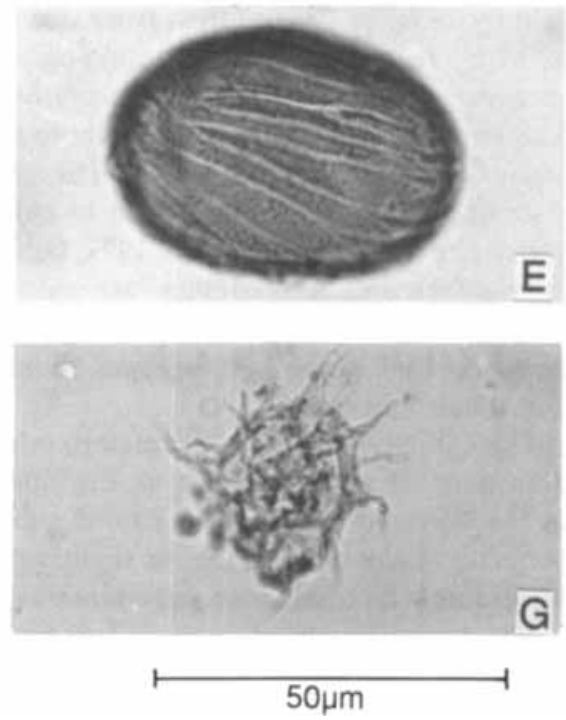

Fig. 10. Selected pollen and one acritarch from Nordaustlandet. Each figured palynomorph is located by abbreviated section name, sample level and PMO number (Palacontological Museum in Oslo) followed by slide coordinates to an England Finder. Magnification $\times 700$. Scale is added.
A. Vittatina subsaccata $\mathrm{S} 2,17 \mathrm{~m}, \mathrm{PMO} 121.765, \mathrm{~N} 27$.
B. Vittatina striata $\mathrm{S} 2.17 \mathrm{~m}, \mathrm{PMO} 121.765, \mathrm{~S} 31$.
C. Vittatina saccata, S2, $17 \mathrm{~m}, \mathrm{PMO} 121.765, \mathrm{~F} 24$.
D. Vittatina simplex, S2, $17 \mathrm{~m}$, PMO $121.763, \mathrm{~L} 15$.

E. Vittatina vittifera, S2, $17 \mathrm{~m}$, PMO 121.764, W18.

F. Tiwarispora flavatus sp. S2, $17 \mathrm{~m}$, PMO 121.763. J15.

G. Micrhystridium sp. S3, $101 \mathrm{~m}$, PMO 121.766. 
Basin are calibrated with the marine fauna. including ammonoids, fusulinids and conodonts (Utting 1989).

The assemblage in the Idunfjellet Member of the upper Nordenskiöldbreen Formation and lowest parts of the Gipshuken Formation comprised characteristic monosaccate pollen. In the Sverdrup Basin (Utting 1985. 1989) monosaccate pollen is recorded in deposits dated as late Moscovian to Sakmarian, also with occasional monosaccates in Artinskian to Roadian deposits. The dominance of Vittatina and Protohaploxypinus recorded in the Idunfjellet Member and the lowest part of the Gipshuken Formation is also a feature of the Weylandites striatus - Protohaploxypinus perfectus and Limitisporites monstruosus - Vittatina costabilis Assemblage Zones of the Sverdrup Basin (Utting 1989). The Weylandites striatus - Protohaploxypinus perfectus Assemblage Zone of late Asselian to early Sakmarian age based on fusulinids (Nassichuk \& Wilde 1977). or late Sakmarian age based on conodonts (Utting 1989, p. 238). differs from our material in being less diverse and containing common specimens of Hamiapollenites tractiferimus. The Svalbard assemblages are also similar to the $\mathrm{Lim}$ itisporites monstruosus - Vittatina costabilis Assemblages Zone of Artinskian to early Kungurian age (Nassichuk \& Wilde 1977: Beauchamp et al. 1989), and both contain rare specimens of Hamiapollenites tractiferinus, although the Svalbard material lacks Limitisporites monstruosus and is more diverse.

Thus. it is possible that the material described here may be of similar age as the upper part of the Weylandites striatus - Protohaplorypinus perfectus Assemblage Zone, or slightly younger, for example Sakmarian to Artinskian age.

The poor assemblage recorded in the middle and upper part of the Gipshuken Formation is not age diagnostic other than indicating a Permian age. The absence of monosaccate pollen might be due to facies changes, but could also indicate a different assemblage.

The assemblage recorded in the Voringen Member with abundant Micrhystridium. is also noted from Upper Permian (Wordian) strata in the Sverdrup Basin (Utting 1989). Similar palynological assemblages are also represented at several other localities on Svalbard (personal observation), including Festningen in western Spitsbergen where the similar assemblage was recorded in beds assigned to the Kungurian . based on brachiopods (Nakamura et al. 1987). The appearance of a number of spore genera might provide a useful tool for establishing a local palynozonation for Svalbard, but at this stage age determinations are speculative.

\section{Environmental interpretation}

In view of the proximity and the similar lithological development of Svalbard and the Sverdrup Basin during the late Paleozoic (Embry 1989), one should expect similar floras in the two areas. The low paleo-latitude, dry climate deduced from sediments dominated by carbonates, evaporites, and red beds in both areas is also demonstrated by the palynofloras being dominated by polyplicate and striate pollen. The bisaccate and monosaccate striated pollen are produced from primitive conifers of a vegetation which tolerates an arid climate (Foster 1979). The appearance of several spore genera in the youngest assemblage suggests a change to a more humid environment.

\section{Thermal maturity}

Evaluation of the thermal maturity was based on the samples from Palanderbukta, observed from colouration of pollen and spores (TAI-values). The preserved pollen grains had TAI-values varying from 1 to 2 (Table 2) corresponding to vitrinite reflection values of $0.25-0.5 \%$. The maturity is low. beyond the oil birth line.

\section{Conclusions}

The palynomorphs of the upper Paleozoic rocks from Nordaustlandet represent three distinct assemblages. The oldest assemblage is tentatively correlated with Sakmarian-Artinskian assemblages recorded in the Sverdrup Basin. The recognition of this assemblage in the lower part of the Gipshuken Formation suggests that this part of the formation could be older than Artinskian, as was suggested by Lauritzen (1981). The very poor. low diversity assemblage in the middle and upper parts of the Gipshuken Formation may be due to a facies change. The distinctly marine palynomorph assemblage recorded in the Vøringen Member of the Kapp Starostin Formation yielded Permian palynomorphs, in addition to 
reworked Carboniferous spores. Age diagnostic palynomorphs have not been found, but the spores appear promising for further work on a palynostratigraphy for the Permian. The time span of the hiatus between the Gipshuken and Kapp Starostin Formations is not known.

Acknowledgements. - We thank Marc B. Edwards and the Norwegian Polar Research Institute for making the samples available, and also $\mathbf{J}, \mathrm{O}$. Vigran and $\mathrm{J}$. Utting for improvements on the manuscript. We thank the Continental Shelf and Petroleum Technology Research Institute (IKU) for support in publishing this paper.

\section{References}

Allan. K. S. 1965: Spore assemblages and their stratigraphical application in the Lower and Middle Devonian of North and Central Vestspitsbergen. Paltoeontology 10 (2) 1967, 280-297.

Bcauchamp, B., Harrison, 3. C. \& Henderson, C. M. 1989: Upper Palcozoic stratigraphy and basin analysis of the Sverdrup Basin, Canadian Arctic Archipelago: Current Research Part G, Geological Survey of Canada, Paper 89-1G, 105-113.

Cutbill. J. L. \& Challinor, A. 1965: Revision of the stratigraphical scheme for the Carboniferous and Permian rocks of Spitsbergen and Bjørnøya. Geological Magazine 102, 418 439.

Dibncr, A. F. 1968: Stratigraphy of the deposits of the Culm sediments of Spitsbergen based on palynological data. Pp. 39-47 in Krasilshchikov, A. A. \& Mirzaev, M. N. (cds.): Geology of the Sedimentary Cover of the Spitsbergen Archipelago. Sevmorgeologija. Leningrad.

Embry, A. 1989: Correlation of Upper Paleozoic and Mesozoic sequences between Svalbard, Canadian Arctic Archipelago, and northern Canada. Pp. 89-98 in Collinson, J. D. (cd.): Correlation in Hydrocarbon Exploration. Norwgian Petroleum Society. Graham and Trotman.

Forbes, C. L. 1960: Carboniferous and Permian Fusulinidae from Spitsbergen. Palueontology 2, 210-225.

Foster. C. B. 1979: Permian plant microfossils of the Blair Athol Coal Measures, Baralaba Coal Measures, and basal Rewan Formation of Oueensland. Geological Survey of Queensland, Pub. 372, Palaeontological Paper 45, 1-244.

Frebold, H. 1939: Das Festungsprofil auf Spitsbergen. V. Stratigraphic und Invertebratenfauna der älteren Eotrias. Ibidem 77. $58 \mathrm{pp}$.
Hoel, A. \& Orvin, A. K. 1937: Das Festungsprofil auf Spitsbergen. Karbon-Kreide 1. Vermessungsresultate. Skr. Stalbard og Ishavet 18, 1-59

Kaiser, M. 1970: Die Oberdevon-Flora der Barcninsel 3. Mikroflora des hoheren Oberdevons und des Unterkarbons. Palaeontographica $129(B), 71-124$.

Kaiser, M. 1971: Dic Oberdevon-Fiora der Bareninsel 4. Mikroflora der Misery-Scric und der Flozleeren Sandstein-Seric. Palaeontographica 135 (B), 127-164.

Lauritzen, Ø. 1981: Investigations of Carboniferous and Permian sediments in Svalbard. Norsk Polarinstitutts Skrifter $176,1-43$.

Lowell, J. D. 1968: Upper Palcozoic and Lower Mesozoic stratigraphy of south-western Nordaustiandet, Spitsbergen. Geological Magazine 105. 348-355.

Malkowski, K. 1982: Development and stratigraphy of the Kapp Starostin Formation (Permian) of Spitsbergen. Palaeont. Polonica 43, 69-81.

Nakamura, K. Kimura, G. \& Winsnes, T. S. 1987: Brachiopod zonation and age of the Permian Kapp Starostin Formation (Central Spitsbergen). Polar Research 5. 207-219.

Nassichuk, W. W. \& Wilde, G. L. 1977: Permian Fusuliniaceans and stratigraphy at Blind Fjord, southwestern Ellesmere Island. Geol. Surv. Can. Bull. 268, 1-59.

Nilsson, I. 1988. Carboniferous - Permian fusulinids on the Nordfjorden Block. Spitsbergen. Svalbard. Univ. of Oslo. unpubl. thesis. $165 \mathrm{pp}$

Playford, G. 1962: Lower Carboniferous microfloras of Spitsbergen. Part 1. Palaeontology 5. 550-618.

Playford, G. 1963: Lower Carboniferous microtloras of Spitsbergen. Part 2. Palaeontology 5, 619-678.

Ross, C. A. 1965: Fusulinids from the Cyathophyllum Limestone, Central Vestspitsbergen. Contr. Cushman Found. Foraminiferal Res. 16, 75-86.

Utting, J. 1985: Preliminary results of palynological studies of the Permian and lowcrmost Triassic sediments. Sabine Pcninsula. Melvillc Island. Canadian Arctic Archipelago. Current Research, Part B, Geological Survey of Canada. Paper 85-1B, 231-238.

Utting. J. 1989: Preliminary palynological zonation of surfacc and subsurface sections of Carboniferous, Permian and lowest Triassic rocks, Sverdrup Basin, Canadian Arctic Archipelago. Current Research, Part G. Geological Survey of Canada. Paper 89-lG, 233-240.

Utting. J., Goodarzi, F., Dougherty, B. J. \& Henderson, C. M. 1989: Thermal maturity of Carboniferous and Permian rocks of the Sverdrup Basin, Canadian Arctic Archipelago. Geological Survey of Canada, Paper 89-19, 1-20.

Virgran, J. O. 1964: Spores from Devonian deposits. Mimerdalen, Spitsbergen. Norsk Polarinstituts Skrifter 132, 33 pp. 
